\title{
Kampanye KOMNAS Perempuan Pada Kampanye 16 Hari Anti Kekerasan Terhadap Perempuan
}

\author{
Wina Puspita Sari, Casa Bilqis Savitri \\ D III Hubungan Masyarakat, Fakultas Ilmu Sosial, Universitas Negeri Jakarta \\ Email: Winapuspitasariunj@,gmail.com, Bilqiscasa@gmail.com \\ Diterima 17 November 2019 / Disetujui 24 Desember 2019
}

\begin{abstract}
The 16 Days Against Women Violence Campaign is a campaign to encourage liberation struggles against women throughout the world. As a national human right in Indonesia. This campaign has been carried out since 2003 and is routinely carried out every period with a 16-day campaign set in November. Problems in the 16-Day Campaign Against Violence Against Women, this campaign has been running for 15 years, but this is not directly proportional to the protected numbers against women has increased over the past three years. The main theory in this research is campaign theory using Nowak \& Warneryd's campaign model. The method used is a descriptive qualitative research method that looks for facts with the right interpretation. Descriptive research on problems in society, views, and processes - ongoing parts and effects of phenomena. Komnas Perempuan is still too broad in setting its campaign targets, as well as a lot of messages to be conveyed. the extent of challenging the campaign audience makes KOMNAS Perempuan against barriers ranging from language and culture, there is a GAP about knowledge of challenges, to obstacles in choosing what campaign techniques to use. In the 16 Days Anti Violence against Women campaign, KOMNAS Perempuan chose to generalize the message to be conveyed, accepting their own challenges, which made the objectives of the 16 Days Anti Violence Against Women Campaign unsuccessful.
\end{abstract}

Keywords: Campaign, KOMNAS Perempuan, Violence

\begin{abstract}
ABSTRAK
Kampanye 16 Hari Anti Kekerasan terhadap Perempuan merupakan kampanye untuk mendorong upaya-upaya penghapusan kekerasan terhadap perempuan di seluruh dunia. Sebagai institusi nasional hak asasi manusia di Indonesia. Kampanye ini dilakukan sejak tahun 2003 yang dilaksanakan secara rutin setiap tahunnya dengan periode kampanye selama 16 hari disetiap bulan November.Masalah dalam Kampanye 16 Hari Anti Kekerasan Terhadap Perempuan ini ialah, kampanye tersebut sudah berjalan selama 15 tahun namun hal tersebut tidak berbanding lurus dengan angka kekerasan terhadap perempuan yang meningkat setidaknya selama tiga tahun kebelakang. Tujuan diadakan penelitian ini ialah untuk mengetahui unsur kampanye serta hambatan apa saja yang dihadapi oleh KOMNAS Perempuan sehingga dapat diketahui apa penyebab kurang tercapainya tujuan dari Kampanye 16 Hari Anti Kekerasan terhadap Perempuan. Teori utama dalam penelitian ini ialah teori kampanye yang menggunakan model kampanye milik Nowak \& Warneryd. Metode yang digunakan ialah metode penelitian kualitatif deskriptif yaitu pencarian fakta dengan interpretasi yang tepat. Penelitian deskriptif mempelajari masalah-masalah dalam masyarakat, pendangan-pandangan, serta proses prorses yang sedang berlangsung dan pengaruh-pengaruh dari suatu fenomena. Dalam penelitian ini diketahui bahwa dalam pelaksanaan kampanye ini Komnas Perempuan masih terlalu luas dalam menetapkan sasaran kampanye, serta terlalu banyak pesan yang ingin disampaikan. luasnya cakupan khalyak kampanye membuat KOMNAS Perempuan menghadapi berbahai hambatan mulai dari
\end{abstract}


hambatan bahasa serta budaya, adanya GAP tentang pengetahuan mengenai kekerasan, hingga hambatan dalam memilih teknik kampanye seperti apa yang harus digunakan. Dalam kampanye 16 Hari Anti Kekerasan terhadap Perempuan, KOMNAS Perempuan cenderung menyamaratakan pesan yang ingin disampaikan sedangkah disetiap daerah memiliki kasus kekerasannya sendiri-sendiri hal tersebut yang membuat tujuan dari Kampanye 16 Hari Anti Kekerasan Terhadap Perempuan belum tercapai.

Kata Kunci: Kampanye, KOMNAS Perempuan, Kekerasan

\section{PENDAHULUAN}

Komisi Nasional Anti Kekerasan Terhadap Perempuan adalah lembaga negara yang independen untuk penegakan hak asasi manusia perempuan Indonesia. Komnas Perempuan dibentuk melalui Keputusan Presiden No. 181 Tahun 1998, pada tanggal 9 Oktober 1998, yang diperkuat dengan Peraturan Presiden No. 65 Tahun 2005. Komnas Perempuan lahir dari tuntutan masyarakat sipil, terutama kaum perempuan, kepada pemerintah untuk mewujudkan tanggung jawab negara dalam menanggapi dan menangani persoalan kekerasan terhadap perempuan. Tuntutan tersebut berakar pada tragedi kekerasan seksual yang terutama dialami oleh perempuan etnis Tionghoa dalam kerusuhan Mei 1998 di berbagai kota besar di Indonesia

Salah satu program yang dilakukan oleh Komnas Perempuan ialah kampanye bertajuk "16 Hari Anti Kekerasan Terhadap Perempuan”. Kampanye 16 Hari Anti Kekerasan terhadap Perempuan (16 Days of Activism Against Gender Violence) merupakan kampanye internasional untuk mendorong upaya-upaya penghapusan kekerasan terhadap perempuan di seluruh dunia. Sebagai institusi nasional hak asasi manusia di Indonesia, Komnas Perempuan menjadi inisiator kegiatan ini di Indonesia. Keterlibatan Komnas Perempuan dalam kampanye 16 Hari Anti Kekerasan Terhadap Perempuan (HAKTP) telah dimulai sejak tahun 2003. Setiap tahun kampanye ini dilaksanakan pada tanggal 25 November hingga 10 Desember. Dipilihnya rentang waktu tersebut adalah dalam rangka menghubungkan secara simbolik antara kekerasan terhadap perempuan dan HAM, serta menekankan bahwa kekerasan terhadap perempuan merupakan salah satu bentuk pelanggaran HAM.

Kampanye 16 Hari Anti Kekerasan Terhadap Perempuan sudah dilaksanakan oleh KOMNAS Perempuan sejak tahun 2003, kampanye tersebut sudah berjalan kurang lebih 16 tahun, namun dalam pelaksaan kampanye tersebut output yang dihasilkan tidak berbanding 
lurus dengan kekerasan terhadap perempuan yang terus meningkat. Berdasarkan data yang dikutip dari Catatan Tahunan milik Komisi Perlindungan Terhadap Perempuan :

1. Ada 259.150 kasus kekerasan terhadap perempuan yang dilaporkan dan ditangani selama tahun 2016, yang terdiri dari 245.548 kasus bersumber pada data kasus/perkara yang ditangani oleh 359 Pengadilan Agama (browsing laman BADILAG), serta 13.602 kasus yang ditangani oleh 233 lembaga mitra pengada layanan, tersebar di 34 Provinsi. Data ini turun dari data tahun sebelumnya karena kendala teknis pendokumentasian di Pengadilan Agama dan perubahan struktur di beberapa layanan berbasis Negara. Tahun 2017 Komnas perempuan mengirimkan 674 lembar formulir kepada lembaga mitra Komnas Perempuan di seluruh Indonesia dengan tingkat respon pengembalian mencapai 34\%, yaitu 233 formulir.

2. Ada 348.446 kasus kekerasan terhadap perempuan yang dilaporkan dan ditangani selama tahun 2017, yang terdiri dari 335.062 kasus bersumber pada data kasus/perkara yang ditangani oleh Pengadilan Agama, serta 13.384 kasus yang ditangani oleh 237 lembaga mitra pengadalayanan, tersebar di 34 Provinsi. Komnas Perempuan mengirimkan 751 lembar formulir kepada lembaga mitra pengadalayanan di seluruh Indonesia dengan tingkat respon pengembalian mencapai $32 \%$, yaitu 237 formulir.

3. Ada 406.178 kasus kekerasan terhadap perempuan yang dilaporkan dan ditangani selama tahun 2018 (naik dari tahun sebelumnya sebanyak 348.466). Kasus kekerasan terhadap perempuan ini terdiri dari 13.568 kasus yang ditangani oleh 209 lembaga mitra pengada layanan yang tersebar di 34 Provinsi, serta sebanyak 392.610 kasus bersumber pada data kasus/perkara yang ditangani oleh Pengadilan Agama.

Teori besar dalam penelitian ini ialah teori kampanye. di dalam teori kampanye terdapat model kampanye, model kampaye yang digunakan sebagai referensi dalam penelitian ini ialah model kampanye milik Nowak \& Warneryd yang mana di dalam model kampanye ini terdapat delapan unsur kampanye yang harus diperhatikan : intented effect (efek yang diharapkan), Competing communication (persaingan komunikasi), Communication Object (Objek Komunikasi), Target Population \& Receiving Group (populasi target dan kelompok penerima), the channel (saluran), the message (pesan), The 
Communicator/sender (komunikator/pengirim pesan), The Obtained Effect (efek yang dicapai)..

Sebagai tinjauan literatur, peneliti mengambil lima penelitian terdahulu dengan subjek menelitian yang sama : Pertama, penelitian yang dilakukan oleh Budi setiawan dan Dini Salmiyah Fithrah yang berisi tentang Kampanye Gerakan Indonesia Diet Kantong Plastik Dalam Membentuk Persepsi Masyarakat Bandung. Tujuan untuk meneliti strategi yang digunakan melalui program Kampanye Rampok Plastik dengan menggali melalui teori proses PR dimulai dari mendefinisikan masalah, perencanaan, bertindak dan evaluasi program. Konsep yang digunakan dalam penelitian ini yaitu public relations, kampanye public relations dan persepsi.

Penelitian ini merupakan penelitian kualitatif deskriptif dengan teknik wawancara. Paradigma yang digunakan dalam penelitian ini yaitu post-positivisme. Hasil penelitian menunjukan bahwa persepsi yang ingin dibentuk yaitu masyarakat mulai menyadari dampak negatif penggunaan kantong plastik. Setelah mengindentifikasi dan menganalisis, kampanye rampok plastik telah mengikuti tahapan dalam proses PR meliputi mendefiniskan masalah, rencana program, bertindak dan evaluasi program. Perbedaan penelitian ini dengan penelitian yang dilakukan oleh peneliti ialah dari tujuan yang ingin diteliti. Jika peneliti sebelumnya bertujuan untuk meneliti strategi kampanye yang digunakan, sedangkan peneliti betujuan untuk mengetahui unsure kampanyenya saja sehingga tidak sampai ketahap evaluasi.

Kedua, penelitian yang dilakukan oleh Dini Safitri, Wina Puspita Sari, Gretia Sembiring yang berjudul Kampanye Pendidikan Karakter Untuk Mencegah Dan Menanggulangi Bullying Di Sosial Media Instagram. Metode yang digunakan dalam penelitian ini adalah metode kualitatif. Metodologi kualitatif, yang digunakan dalam penelitian ini adalah metode netnografi. Menurut Kozinets, netnografi adalah metode penelitian yang khusus dirancang untuk mempelajari budaya dan komunitas online. Kozinets mengganti lapangan kerja etnografi menjadi Computer Mediated Communication (CMC), atau komputer yang memediasi interaksi.

Metode netnografi dipilih sebagai metode dalam penelitian ini, karena penelitian ini menggunakan internet yaitu akun Instagram stopbullyunj sebagai lapangan penelitian. Hal tersebut disebabkan oleh semakin banyak orang menggunakan internet, mereka 
memanfaatkan sebagai alat komunikasi yang memungkinkan untuk memberdayakan pembentukan masyarakat, sehingga tercipta budaya baru yang diciptakan melalui komputer dan dimediasi dengan interaksi sosial. Perbedaan dari penelitian ini dengan penelitian yang dilakukan oleh peneliti terdapat pada metodenya, yang mana metode yang digunakan oleh peneliti ialah kualitatif deskriptif yang mana peneliti hanya menjabarkan realitas secara langsung, serta melakukan wawancara secara langsung bukan mengamati via online.

Ketiga, penelitian yang dilakukan oleh Eriyanto dan Irwa Zarkasi yang berjudul Kampanye Bahaya Rokok Dan Pendekatan Rasa Takut (Fear Appeal). Tujuan penelitian ini adalah menilai apakah kampanye bahaya rokok telah memenuhi syarat pesan persuasi yang baik. Teori yang dipakai adalah Extended Parallel Process Model (EPPM) dari Kim Witte. Pesan persuasi sebaiknya mengandung dua aspek, yaitu memberikan ancaman mengenai bahaya rokok dan sekaligus memberi jalan keluar berupa rekomendasi bahwa seseorang bisa menghindari bahaya rokok. Metode penelitian yang dipakai adalah riset evaluasi (evaluation research). Perbedaan dengan penelitian yang dilakukan oleh peneliti ialah, dimana penelitian yang dilakukan oleh peneliti menggunakan teori model kampanye milik Nowak \& Warneryd yang mana teori tersebut berfokus pada unsur-unsur yang terdapat di dalam kampanye.

Keempat, penelitian yang dilakukan oleh Ratih Firdiyah dan Winda Primasari dengan judul Kampanye Sosial Gerakan Menutup Aurat di Bekasi. Penelitian ini meneliti kampanye sosial yang digunakan oleh GEMAR dalam perspektif model kampanye lima tahap fungsi pembangunan. Metode penelitian yang digunakan dalam penelitian ini adalah metode penelitian kualitatif deskriptif melalui wawancara mendalam yang diterapkan dalam proses pengumpulan datanya. Temuan penelitian menunjukkan bahwa dengan mengikuti lima tahap fungsional pembangunan, GEMAR dapat membangkitkan kesadaran perempuan muslim di Bekasi untuk memakai busana muslimah atau syar'i. perbedaannya dengan penelitian yang dilakukan oleh peneliti ialah terdapat pada model yang digunakan, jika penelitian ini menggunakan model kampanye lima tahap fungsi pembangunan sedangkan penelitian yang dilakukan oleh peneliti menggunakan model kampanye milik Nowan \& Warneryd yang mana terdapat delapan unsur dalam kampanye.

Kelima, penelitian yang dilakukan oleh Raden Meisa Merseli dan M.E Fuady dengan judul Kegiatan Kampanye Internet Sehat Oleh Diskominfo Melalui Mobil Internet Gratis. Dalam penelitian ini bertujuan untuk memaparkan dan menentukan keberhasilan kampanye: (1) kondisi masalah sebenarnya; (2) syarat-syarat mengurangi masalah; (3) 
perilaku anggota masyarakat; (4) mengkontruksi isi dan pesan; (5) karakteristik khalayak sasaran' (6) pesan yang disampaikan; (7) Aktor Kampanye; (8) kredibilitas sumber; (9) teknik pelaksanaan kampanye; (10) pesan tersampaikan kepada khalayak, (11) pesan diterima oleh khalayak, (12) pesan diingat oleh khalayak. Metode yang digunakan dalam penelitian ini adalah deskriptif data kualitatif melalui teknik wawancara mendalam, observasi, studi pustaka, media elektronik atau internet. Penelitian ini dilakukan untuk memaparkan dan mengetahui keberhasilan kegiatan kampanye internet sehat yang dilakukan Diskominfo melalui mobil internet gratis.

Berdasarkan hasil penelitian ditemukan proses kegiatan Kampanye Internet Sehat diantaranya: (1) Mengetahui kondisi masalah penyalahgunaan internet; (2) Bekerja sama dengan Kominfo terkait dalam kegiatan kampanye; (3) melakukan survei ke lokasi sebelumnya; (4) menyediakan fasilitas layanan Mobil Internet Gratis; (5) kalangan remaja lebih rentan terhadap penyalahgunaan internet; (6) materi mengenai penggunaan internet; (7) relawan TIK dan tim Diskominfo; (8) memiliki daya tarik; (9) isu yang dilaporkan menjadi bahan materi, materi Internet Sehat akan selalu ada, berdurasi 3 jam dan peserta kurang lebih 300 orang; (10) pengemasan pesan mudah dicerna; (11) narasumber mampu membangun suasana; (12) mampu menjawab sesi tanya jawab.

Perbedaan dengan penelitian yang dilakukan oleh peneliti ialah jika penelitian ini bertujuan untuk memaparkan dan menentukan keberhasilan kampanye, sedangkan penelitian yang dilakukan oleh peneliti adalah untuk memaparkan apa saja unsur yang terdapat dalam kampanye 16 hari anti kekerasan terhadap perempuan sehingga diketahu hambatan yang terjadi dan mengetahui faktor penyebab dari belum dapatnya menekan angka kekerasan terhadap perempuan.

\section{METODE PENELITIAN}

Metode penelitian yang digunakan ialah metode penelitian kualitatif deskriptif yaitu sebagai suatu pendekatan atau penelusuran untuk mengeksplorasi dan memahami suatu gejala sentral. Peneliti mewawancarai peserta penelitian atau partisipan dengan mengajukan pertanyaan yang umum dan agak luas. Informasi yang disampaikan oleh partisipan kemudian dikumpulan. Informasi tersebut biasanya berupa kata atau teks. Data yang berupa kata-kata atau teks tersebut kemudian dianalisis. Hasil analisis dapat berupa penggambaran atau deskripsi atau dapat pula dalam bentuk tema-tema. Penelitian ini hanya 
menggambarkan realiras objek penelitian yang diteliti secara baik, utuh, jelas dan sesuai dengan fakta yang tampak.

\section{HASIL DAN PEMBAHASAN Hasil Penelitian}

Kampanye ini sudah berjalan selama 15 tahun mulai dari tahun 2003. 10 tahun sebelumnya kampanye 16 Hari Anti Kekerasan Terhadap Perempuan berfokus untuk mengedukasi masyarakat tentang bagaimana mengenali dan menangani kekerasan seksual, sedangkan untuk 5 tahun ini Komnas Perempuan berfokus pada ranah hukum mengenai kekerasan seksual yaitu RUU Penghapusan Kekerasan Seksual.

Target sasaran dari kampanye 16 hari anti kekerasan terhadap perempuan ini ialah masyarakat seluruh Indonesia, terutama remaja. Yang menjadi alasan mengapa Komnas Perempuan memilih remaja sebagai target sasaranya ialah menurut data CATAHU setiap tahunnya, masyarakat berusia remajalah yang banyak menjadi korban. Mengenalkan kampanye tentang kekerasan seksual selama 5 tahun di awal ini mengalami problemnya sendiri ketika kampanye ini turun sampai ditataran implementasi ke publiknya karena sasaran publiknya yang bermacam-macam dikarenakan ketika kampanye ini sampai ke daerah dikarenakan kata "seksual” acap kali masih dianggap sebagai hal yang tabu.

Dalam menjalankan kampanye 16 hari anti kekerasan terhadap perempuan, Komnas Perempuan bekerja sama dengan berbagai mitra yang ada di daerah di Indonesia guna untuk membantu mensosialisasikan perihal kampanye tersebut. Selain bekerja sama dengan mitra daerah, Komnas Perempuan dalam menjalankan kampanye 16 hari anti kekerasan terhadap perempuan bekerja sama dengan beberapa sektor privat yang berguna untuk menggalang dana serta meningkatkan awareness di masyarakat.

Komnas Perempuan juga bekerjasama dengan organisasi terkait yang memiliki tujuan yang sama dengan Komnas Perempuan. Dikarenakan dalam rangkaian 16 hari kampanye, terdapat hari-hari lain juga yang dirayakan seperti hari HAM, hari volunteer, dll. Bentuk kerjasamanya ialah menggambungkan isu yang dibawa oleh organisasi terkait dengan isu mengenai kekerasan terhadap perempuan, sehingga 16 hari anti kekerasan terhadap perempuan bukan hanya milik Komnas Perempuan. 
Dalam melakukan kampanye 16 hari anti kekerasan terhadap perempuan, komnas menggunakan beberapa saluran kampanye seperti sosial media,diskusi publik, pawai, dll. Namun saluran kampanye tersebut tidak diterapkan diseluruh kota di Indonesia, hanya di kota-kota tertentu saja.

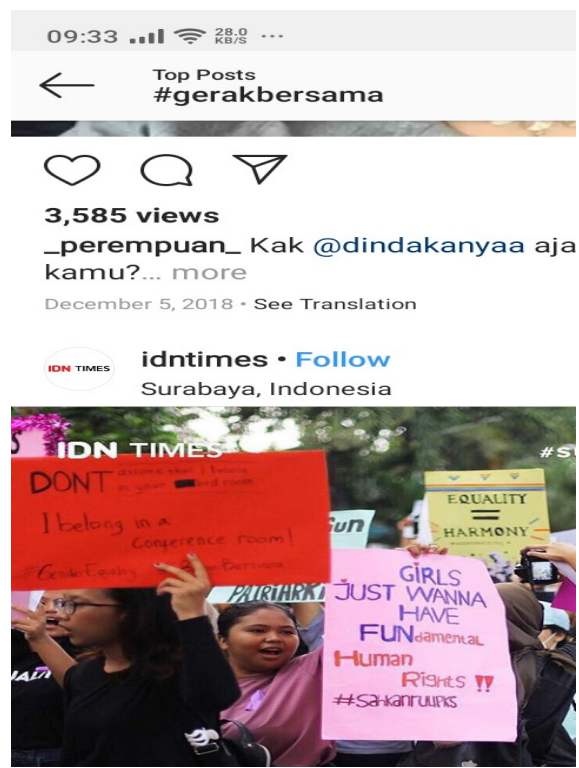

\section{Gambar1. Kegiatan \#gerakbersama Sumber instagram: Hastag \#gerakbersama}

Setiap tahunnya kampanye 16 hari anti kekerasan terhadap perempuan mengangkat isu yang berbeda-beda, mulai dari pengenalan tentang apa itu kekerasan terhadap perempuan sampai dengan membahas masalah payung hukum mengenai kekerasan. Dengan khalayak sasaran kampanye yang begitu luas komnas membagi strategi kampanyenya menjadi beberapa region. Untuk di daerah timur seperti Papua, Komnas Perempuan harus memikirkan kembali strategi kampanye yang harus digunakan mengingat untuk di daerah timur masih terdapat GAP tekhnologi yang mana pendekatan kampanyenya tidak bisa dilakukan secara online.

Selain itu ada tantangan sendiri bagi Komnas Perempuan dimana akitivis yang berusia muda sangatlah jarang di daerah timur seperti Papua. Dalam melakukan kampanye 16 hari anti kekerasan terhadap perempuan, komnas menggunakan beberapa saluran kampanye seperti sosial media,diskusi publik, pawai, dll. Namun saluran kampanye tersebut tidak diterapkan diseluruh kota di Indonesia, hanya di kota-kota tertentu saja. 
Selama 16 tahun berjalan kampanye ini masih belum cukup mampu untuk menekan angka kekerasan seksual meskipun Komnas walaupun berbagai strategi kampanye sudah dilakukan. Hal itu disebabkan oleh luasnya khalayak sasaran serta GAP yang terjadi diantara setiap khalayak yang tersebar diberbagai daerah di Indonesia. Komnas Perempuan mengaku cukup kesulitan jika harus bekerja sendirian, masyarakat harus ikut membantu dalam kampanye 16 hari anti kekerasan terhadap perempuan. Dalam menjalankan kampanye 16 hari anti kekerasan terhadap perempuan, Komnas Perempuan dihadapkan oleh beberapa hambatan salah satunya ialah adanya GAP pengetahuan di masyarakat antara masyarakat yang sudah tau dan belum mengetahui tentang kekerasan terhadap perempuan. Pesan yang disampaikan dalam kampanye terkadang maknanya tidak sesuai dengan apa yang diinginkan oleh Komnas Perempunan. Template kampanye disamaratakan di setiap daerah dan template kampanye tesebut ditentukan berdasarkan kesepakatan di level yang paling umum hal tersebut membuat pesan terkadang tidak sampai dikarenakan setiap daerah punya isu kekerasannya sendiri dan punya budayanya sendiri.

Hambatan juga datang dari beberapa kelompok yang menolak RUU PKS yang mana isu RUU PKS ini yang sedang menjadi topik kampanye 16 hari anti kekerasan terhadap perempuan, ada beberapa kelompok yang menganggap bahwa RUU ini bertentangan dengan salah satu ajaran agama. Komnas Perempuan menyiasatinya dengan bekerja sama dengan KUPI (Kongres Ulama Perempuan Indonesia), yang mana KUPI menurut Komnas Perempuan ialah lembaga yang memiliki kapabilitas dalam di bidangnya.

\section{Pembahasan}

Komnas Perempuan sebagai komunikator melalukan kegiatan komunikasi melalui kegiatan kampanye 16 hari anti kekerasan terhadap perempuan dengan tujuan untuk mengubah perilaku masyarakat agar lebih memahami tentang apa itu kekerasan terhadap perempuan, dan mendorong masyarakat untuk membuat gerakan serupa dengan tujuan untuk mengurangi tindakan kekerasan terhadap perempuan yang kian meningkat.

Menurut tingkatan komunikasi yang dikemukakan oleh Dennis Mcquaill Komnas Perempuan menggunakan tingkatan komunikasi antar kelompok/ asosiasi dan komunikasi dengan masyarakat luas yang mana Komnas Perempuan banyak bekerjasama dengan mitramitra di daerah dan sektor privat dalam menjalankan kampanye 16 hari anti kekerasan terhadap perempuan mengingat target sasaran dari kampanye tersebut sangatlah luas. 
Komnas Perempuan sebagai lembaga negara mempunyai peran dan tanggung jawab untuk Meningkatkan upaya pencegahan dan penanggulangan segala bentuk kekerasan terhadap perempuan dan perlindungan hak-hak asasi perempuan. Kampanye 16 hari anti kekerasan terhadpa perempuan ialah sebuah upaya Komnas Perempuan dalam memberikan pengertian kepada masyarakat mengenai bentuk kekerasan terhadap perempuan serta bagaimana cara menanggulanginya dan sebuah upaya Komnas Perempuan dalam mendorong tingkah laku masyarakat agar turut menghapuskan tindak kekerasan terhadap perempuan.

Adanya kampanye 16 hari anti kekerasan terhadap perempuan perlu diketahui masyarakat, terutama masyarakat yang belum mengetahui apa itu kekerasan terhadap perempuan, untuk masyarakat mengetahui hal tersebut perlu diadakannya sebuah strategi dalam mensosialisasikan dan mempublikasikannya. Ini terbukti bahwa masih ada masyarakat yang belum mengetahui tentang kampanye 16 hari anti kekerasan terhadap perempuan, maka oleh sebab itu masih banyak masyarakat yang tidak mengetahui apa itu kekerasan terhadap perempuan sehingga angka kekerasan terhadap perempuan kian meningkat setidaknya selama 3 tahun belakanganHal tersebut menjelaskan bahwa strategi kampanye yang dilakukan oleh Komnas Perempuan dalam melakukan sosialisasi kampanye 16 hari anti kekerasan terhadap perempuan masih kurang baik, untuk berhasilnya sebuah persuasi dalam berkampanye melalui berbagai teknik agar dalam penyampaian pesan kepada audiensinya cukup efektif. Dalam hal ini Komnas Perempuan menggunakan model kampanye Nowak dan Warneryd, menurut McQuail \& Windahl. Pada model Nowak dan Warneryd, terdapat tujuh elemen kampanye yang harus diperhatikan, yaitu Intented effect (efek yang diharapkan), Competing communication (persaingan komunikasi), Communication Object (Objek Komunikasi), Target Population \& Receiving Group (populasi target dan kelompok penerima), The Channel (saluran), The Message (pesan), The Communicator/sender (komunikator/pengirim pesan), The Obtained Effect (efek yang dicapai). Dalam melakukan strategi kampanye, Komnas Perempuan menggunakan 8 elemen dalam model kampanye milik Nowak Warneryd tersebut, sebagai berikut;

\section{Intented Effect (Efek Yang Diharapkan)}

Efek yang diharapkan dari kampanye 16 hari anti kekerasan terhadap perempuan ialah untuk menggalang gerakan solidaritas berdasarkan kesadaran bahwa kekerasan terhadap perempuan merupakan pelanggaran HAM, meningkatkan pemahaman mengenai kekerasan berbasis jender sebagai isu Hak Asasi Manusia di tingkat lokal, membangun 145 ICommunicology Vol. 7 ( no) 2 Tahun 2019 
gerakan anti kekerasan terhadap perempuan untuk memperkuat tekanan terhadap pemerintah agar melaksanakan dan mengupayakan penghapusan segala bentuk kekerasan terhadap perempuan.

\section{Competing Communication (Persaingan Komunikasi)}

Dalam melakukan kampanye 16 hari anti kekerasan terhadap perempuan, Komnas Perempuan memiliki berbagai hambatan salah satunya ialah masyarakat yang kontra terhadap kampanye tersebut. Komnas Perempuan dihadapkan oleh situasi dimana sebagian masyarakat menolak isi dari kampanye tersebut dengan dalil bahwa isi kampanye tersebut tidak sesuai dengan ajaran salah satu agama di Indonesia. Dalam mensiasati competing communication, Komnas Perempuan menggandeng sebuah asosiasi yaitu KUPI (Kongres Ulama Perempuan Indonesia) yang mana asosiasi tersebut cukup kredibel di bidangnya. Selain itu Komnas Perempuan selalu berusaha untuk melakukan pendekatan terhadap pihak yang kontra, namun usaha yang dilakukan dinilai sia-sia karena tidak mendapatkan feedback yang diinginkan.

\section{Communication Object (Objek Komunikasi)}

Objek kampanye biasanya dipusatkan pada satu hal karena untuk objek yang berbeda, menghendaki metode komunikasi yang berbeda. Dalam hal ini objek komunikasi dari kampanye 16 hari anti kekerasan terhadap perempuan ini ialah seluruh masyarakat di Indonesia. Dengan cakupan objek komunikasi yang luas, Komnas Perempuan menghendaki metode komunikasi yang berbeda. Metode komunikasi yang dilakukan oleh Komnas Perempuan disesuaikan oleh budaya serta daerah dimana objek komunikasi tersebut berada dikarenakan setiap daerah memiliki budaya yang berbeda-beda sehingga diperlukan pendekatan yang sesuai dengan budaya tersebut agar pesan yang disampaikan bisa diterima dengan baik.

Metode komunikasi yang dilakukan oleh Komnas Perempuan untuk di daerah Timur Indonesia lebih fokus di ranah offline dikarenakan minimnya akses internet sehingga metode komunikasi seperti diskusi publik dinilai yang paling pas untuk diterapkan. Sedangkan untuk di daerah Jawa, metode yang digunakan lebih ke ranah online, seperti lewat sosial media. Walaupun metode komunikasi offline seperti diskusi publik dan seminar, serta workshop yang dilakukan di berbagai kota dalam rentang waktu 16 hari.

\section{Target Population \& Receiving Group (Populasi Target Dan Kelompok Penerima)}

Agar penyebaran pesan dalam kampanye 16 hari anti kekerasan terhadap perempuan mudah lebih mudah dilakukan, penyebaran pesan dilakukan melalui opinion 
leader terumana untuk populasi target di daerah Timur yang mana pesan lebih ditujukan kepada opinion leader dengan tujuan agar pesan yang disampaikan dalam kampanye 16 hari anti kekerasan terhadap perempuan lebih mudah diterima di masyarakat mengingat ketika pesan mengenai kekerasan seksual diimplementasikan di daerah mengalami kesulitan tersendiri. Kaata "seksual" masih dianggap tabu di daerah sehingga butuh opinion leader agar pesan tersebut dapat diterima di masyarakat daerah.

\section{The Channel (Saluran)}

Saluran kampanye yang digunakan oleh Komnas Perempuan bermacam-macam disesuaikan oleh karakteristik kelompok. Dalam melakukan kampanye 16 hari anti kekerasan terhadap perempuan, komnas menggunakan beberapa saluran kampanye seperti sosial media,diskusi publik, pawai, dll. Komnas Perempuan mengadakan diskusi publik yang bekerja sama dengan lembaga lain seperti At America, atau organisasi lain seperti Organisasi pembela HAM, organisasi HIV aids yang mana diskusi tersebut membahas seputar isu dari setiap kasus yang diwenangi oleh organisasi terkait yang benang merahnya masih seputar kekerasan terhadap perempuan.

Komnas Perempuan memiliki timeline strategi kampanye online salah satunya melalui website milik Komnas Perempuan yang mana Komnas Perempuan memiliki page tersendiri untuk membahas seputar kampanye 16 hari anti kekerasan terhadap perempuan. Selain itu Komnas Perempuan juga memanfatkan sosial media yaitu instagram dengan cara melakukan kolaborasi dengan kolaborator dikarenakn Komnas Perempuan tidak memiliki akun instagram sendiri. Lewat instagram biasanya Komnas Perempuan melakukan live instagram yang mana masyarakat dapat merespon langsung lewat kolom komentar.

Dikarenakan dalam kampanye 16 hari anti kekerasan terhadap perempuan bekerjasama dengan mitra-mitra di daerah, Komnas Perempuan membebaskan para mitra di daerah untuk memilih saluran kampanyenya sendiri sehingga media yang digunakan dalam kampanye 16 hari anti kekerasan terhadap perempuan tidaklah serempak.

\section{The Message (Pesan)}

Secara garis besar tema pesan dalam kampanye 16 hari anti kekerasan terhadap perempuan mengambil tema yang paling umum, dimana tema tersebut didapatkan berdasarkan konsolidasi nasional oleh Komnas Perempuan dan mitranya, hal tersebut yang terkadang menjadi kendala dimana disetiap daerah memiliki isunya sendiri-sendiri. 


\section{The Communicator/Sender (Komunikator/Pengirim Pesan)}

Efek kampanye meliputi efek kognitif (perhatian,peningkatan, pengetahuan, dan kesadaran), afektif (behubungan dengan perasaan mood, dan sikap), serta konatif (keputusan bertindak dan penerapan). Berdasarkan evaluasi yang dilakukan oleh Komnas Perempuan selama setahun terakhir, kampanye 16 hari anti kekerasan terhadap perempuan mencapai efek kognitif dan konatif, dikarenakan dengan adanya kampanye 16 hari anti kekerasan terhadap perempuan sudah ada beberapa masyarakat yang mengetahui apa itu kekerasan seksual dan menurut Komnas Perempuan semakin muncul inisiatif baru untuk melakukan gerakan yang sama walaupun hal tersebut belum dapat menekan angka kekerasan terhadap perempuan setidaknya selama 3 tahun terakhir.

\section{The Obtained Effect (Efek Yang Dicapai)}

Berdasarkan evaluasi yang dilakukan oleh Komnas Perempuan selama setahun terakhir, kampanye 16 hari anti kekerasan terhadap perempuan mencapai efek kognitif dan konatif, dikarenakan dengan adanya kampanye 16 hari anti kekerasan terhadap perempuan sudah ada beberapa masyarakat yang mengetahui apa itu kekerasan seksual dan menurut Komnas Perempuan semakin muncul inisiatif baru untuk melakukan gerakan yang sama walaupun hal tersebut belum dapat menekan angka kekerasan terhadap perempuan setidaknya selama 3 tahun terakhir.

Ada beberapa faktor yang menghambat kampanye 16 hari anti kekerasan terhadap perempuan :

a) Program-program kampanye tersebut tidak menetapkan khalayak sasarannya secara tepat. Mereka mengalamatkan kampanye tersebut kepada semua orang. Komnas Peremouan menargetkan khalayak dari kampanye 16 hari anti kekerasan terhadap perempuan ialah seluruh masyarakat di Indonesia.

b) Pesan kampanye 16 hari anti kekerasan terhadap perempuan tidak cukup mampu memotivasi khalayak untuk menerima dan menerapkan gagasan yang diterima dikarenakan pembahasan yang terlalu luas serta kurang maksimalnya platform media yang digunakan.

c) Kegagalan pada sebuah program kampanye yang berorientasi perubahan sosial juga dapat terjadi karena pelaku kampaye terlalu mengandalkan media massa tanpa menindaklanjutinya dengan kominikasi antarpribadi. Kampanye 16 hari terhadap perempuan tidak memiliki strategi komunikasi antar pribadi untuk merangkul 
masyarakat yang belum tertarik terhadap isu tersebut. Komnas perempuan hanya melakukan seminar, diskusi publik yang mana orang yang datang ke acara tersebut sudah memiliki concern terhadap isu kekerasan terhadap perempuan sedangkan untuk masyarakat yang belum memiliki concern ke isu tersebut Komnas Perempuan belum memiliki strategi apapun.

\section{PENUTUP}

Berdasarkan hasil penelitian yang telah dilakukan oleh penulis mengenai Strategi Kampanye Komisi Nasional Anti Kekerasan Terhadap Perempuan dengan studi deskriptif terkait Strategi Kampanye 16 Hari Anti Kekerasan Terhadap Perempuan, dapat diambil beberapa kesimpulan. Kesimpulan tersebut yaitu kampanye 16 hari anti kekerasan terhadap perempuan yang dilakukan oleh KOMNAS Perempuan menggunakan unsur kampanye berdasarkan model kampanye milik Nowak \& Warneryd. Efek yang diharapkan dari kampanye ini belum sesuai dengan hasil akhirnya dikarenakan angka kekerasan terhadap perempuan masih terus meningkat selama 3 tahun terakhir, objek komunikasi yang terlalu luas membuat isi pesan dalam kampanye ini tidak sampai terutama saat diimplementasikan ke daerah. Saluran kampanye yang digunakan juga belum maksimal dikarenakan KOMNAS Perempuan hanya mengandalkan website dan tidak memanfaatkan secara maksimal sosisal media yang lainnya.

Persaingan komunikasi juga menjadi salah satu penghambat dalam kampanye tersebut dikarenakan terdapat kelompok masyarakat yang menolak isi pesan dari kampanye 16 hari anti kekerasan terhasap perempuan karena dianggap bertentangan dengan kepercayaan yang mereka anut. Selain itu hambatan juga terjadi pada pemilihan kalimat dalam isi pesan kampanye 16 Hari Anti Kekerasan Terhadap Perempuan yang mana kata "seksual” sendiri masih dianggap sebagai kata yang tabu.

\section{DAFTAR PUSTAKA}

Budi Setiawan \& Dini Salmiyah Fithrah. (2018). Kampanye Gerakan Indonesia Diet Kantong Plastik Dalam Membentuk Persepsi Masyarakat Bandung. Jurnal Manajemen Komunikasi, Volume 2

Eriyanto \& Irwa Zarkasi. (2017) Kampanye Bahaya Rokok Dan Pendekatan Rasa Takut (Fear Appeal). Jurnal ASPIKOM. Volume 3. No.2

Dini Safitri, Wina Puspita Sari, Gretia Sembiring.(2018). Kampanye Pendidikan Karakter Untuk Mencegah Dan Menanggulangi Bullying Di Sosial Media Instagram 
Ratih Firdiyah \& Winda Primasari. (2018). Kampanye Sosial Gerakan Menutup Aurat di Bekasi. Jurnal Ilmu Komunikasi. Volume 16, Nomor 1

Raden Meisa Mersel \& E. Fuady. (2017). Kegiatan Kampanye Internet Sehat Oleh Diskominfo Melalui Mobil Internet Gratis. ISSN: 2460-6510 